\title{
COFRADÍAS ÉTNICAS EN LA ESPAÑA MODERNA: UNA APROXIMACIÓN AL ESTADO DE LA CUESTIÓN
}

\author{
POR \\ ESTEBAN MIRA CABALLOS \\ Universidad de Sevilla
}

\section{RESUMEN}

En este artículo realizamos un pequeño recorrido por las cofradías étnicas localizadas hasta la fecha en España. Nuestro objetivo ha sido doble, por un lado, sintetizar lo ya conocido y, por el otro, aportar nuevos datos, obtenidos a pie de archivo. La principal conclusión a la que hemos llegado es que estos institutos estuvieron más extendidos de lo que se había pensando. Proliferaron a lo largo y ancho del Imperio de los Habsburgo. En España estuvieron totalmente aceptados y fueron favorecidos por las autoridades ya que contribuían a la paz social, a la integración de todos los cristianos y a la promoción social de estas minorías desfavorecidas.

\section{PALABRAS CLAVES}

España; cofradías; negros; moriscos; gitanos.

\section{BROTHERHOODS ETHNIC IN SPAIN MODERN: STATE OF THE QUESTION}

\author{
ABSTRACT \\ In this paper, we make a small tour of the ethnic brotherhoods to date \\ in Spain. Our aim has been twofold, first, summarize what is known and, on \\ the other, provide new data, obtained on the bottom of file. The main \\ conclusion we draw is that these institutes were more widespread than
}


previously thought. Proliferated throughout the Hapsburg Empire. In Spain they were fully accepted and were favoured by the authorities and contributing to social peace, the integration of all Christians and social advancement of those disadvantaged minorities.

\section{KEY WORDS}

Spain; brotherhood; black; moors; gypsies.

$\begin{array}{ll}\text { Recibido/Received } & 14-01-2011 \\ \text { Aceptado/Accepted } & 15-05-2014\end{array}$

Existe ya una larga trayectoria historiográfica sobre las cofradías étnicas, referida a España y a las colonias hispanoamericanas. Su existencia se justificaba precisamente por la discriminación que sufrían estas minorías que, con frecuencia, veían vetado su acceso a las corporaciones de blancos y a sus beneficios espirituales y materiales. La inmensa mayoría de ellas, en una cláusula casi rutinaria, prohibía el acceso a toda persona negra, mulata, morisca o que desempeñase oficios viles. ${ }^{1}$ Es cierto que en teoría no debería haber existido esta discriminación porque los esclavos estaban bautizados y, por tanto, eran cristianos. Precisamente dado que no había un fundamento jurídico para su exclusión, en muchas reglas se solventó la cuestión añadiendo alguna coletilla del tipo para evitar murmuraciones, por no dar lugar a escándalos o por ser gente de su natural inquieta.

Para el caso de Portugal disponemos del trabajo de Didier Lahon en el que se revela la existencia de decenas de cofradías de negros de muy diversas advocaciones, aunque predominan las de San Benito de Palermo,

${ }^{1}$ Hay cientos de ejemplos de este tipo, por lo que nos limitaremos a citar un par de casos: la Hermandad de Ánimas de la iglesia del Salvador de Sevilla, en el capítulo III de sus reglas de 1567, decía lo siguiente: Y asimismo no reciban a ningún morisco, ni mulato, ni a hombre casado con mujer de ese color que sea conocida ser negra o mulata o morisca herrada, salvo que todos los cofrades sean personas llanas $y$ abonadas $y$ de buena vida $y$ fama... Sánchez Herrero, J. (ed.) 2002. CXIX reglas de hermandades y cofradías andaluzas, siglos XIV, XV y XVI: 310. Huelva: Universidad. Asimismo, en las reglas del Gran Poder de Sevilla de 1570, se excluía a las minorías étnicas incluso para desempeñar el oficio de muñidor. Mira Caballos, E. 2004. Las reglas del Gran Poder de Sevilla de 1570. Transcripción y estudio: 31. Sevilla, Excmo. Ayuntamiento. 
las de Jesús y las de María. ${ }^{2}$ En lo referente a las colonias, las cofradías étnicas fueron infinitamente más numerosas y abundantes, sencillamente por el alto porcentaje de población de color. Proliferaron a lo largo y ancho del continente americano existiendo, por ejemplo, varias decenas de ellas en México, 17 en Perú, 12 en Caracas y cinco respectivamente en Panamá y en Santo Domingo. ${ }^{3}$ En algunos lugares, los esclavos se agrupaban por etnias, pues, en Santo Domingo los negros biáfaras y los mandingas eran de la cofradía de la Candelaria, mientras que los ararás se aglutinaban en torno a la de San Cosme y San Damián. ${ }^{4}$

Sin embargo, en lo concerniente a España hasta fechas muy recientes apenas conocíamos la existencia de unas pocas cofradías, localizadas en núcleos con grandes mercados de esclavos como Sevilla o Cádiz. No en vano, Antonio Domínguez Ortiz, gran conocedor de la temática, afirmó que estas asociaciones étnicas se restringieron exclusivamente a las capitales andaluzas. ${ }^{5}$ Sin embargo, como veremos en este trabajo, no fue exactamente así pues proliferaron en muy distintos lugares, especialmente en la España meridional ya que es en esta parte de la Península donde se concentraba el mayor número de aherrojados.

\section{COFRADÍAS ÉTNICAS EN LA ESPAÑA MODERNA}

A medida que avanzan los estudios sobre la esclavitud constatamos la magnitud de estos institutos tanto en España como en sus colonias

${ }^{2}$ Lahon, D. 2000. "Exclusión, intégration et métissage dans les confréries noires au Portugal XVle-XIXe siècle", en Negros, mulatos, zambaigos. Derroteros africanos en los mundos ibéricos: 275-311. Sevilla: Escuela de Estudios Hispanoamericanos.

${ }^{3}$ Gutiérrez Azopardo, I. "Los negros y la Iglesia en la España de los siglos XV y XVI" en http://www.africafundación.org (consulta del 4 de marzo de 2010). Las panameñas se intitulaban así: de San Sebastián, de San Juan de Buenaventura, de Nuestra Señora, de Nuestra Señora de la Concepción y de Santa Ana. De otra más, la de la Caridad, ofrece noticias sobre un proyecto de fundación datado en 1765. Mena García, C. 2000. "Religión, etnia y sociedad: cofradías de negros en el Panamá colonial". Anuario de Estudios Americanos, LVII, 1: 143. En Santo Domingo estaban erigidas las siguientes: la del Espíritu Santo, la de San Cosme y San Damián, Nuestra Señora de la Candelaria, Santa María Magdalena y San Juan Bautista. Larrazábal Blanco, C. 1998, Los negros y la esclavitud en Santo Domingo: 134-135. Santo Domingo: Librería La Trinitaria.

${ }^{4}$ Real Cédula a la audiencia de Santo Domingo para que informe de cierta cofradía de negros Biáfaras, intitulada de Nuestra Señora de la Candelaria que hay en la Catedral, Aranjuez, 9 de septiembre de 1612. AGI, Santo Domingo 869, L. 6, f. 154v.

${ }^{5}$ Domínguez Ortiz, A. 2001. España, tres milenios de Historia: 247. Madrid: Marcial Pons. 
americanas. Un fenómeno asociativo que estuvo bastante más generalizado de lo que inicialmente sospechó la historiografía.

Estas cofradías étnicas eran muy variadas: las había de negros, pero también de mulatos y hasta de moriscos, como la del Espíritu Santo ubicada, desde mediados del siglo XVI, en el hospital del mismo nombre de Triana (Sevilla). ${ }^{6}$ Pero, incluso, dentro de las cofradías participadas por negros no todas eran iguales: las había abiertas a negros, mulatos y a blancos, mientras que otras eran exclusivamente de negros -tanto esclavos como libertos-, es decir, teóricamente cerradas. Pero digo que teóricamente porque legalmente no solían prohibir la pertenencia a ellas de blancos sino que sencillamente ninguno se adscribía, probablemente por motivos raciales, sociales y/o culturales. También encontramos asociaciones que nosotros hemos llamado multiétnicas, pues admitían no sólo a personas de color, sino también a moriscos y a gitanos.

A continuación sintetizamos en el Cuadro I las cofradías de morenos que hasta ahora tenemos localizadas, incluyendo su advocación, la localidad y el siglo fundacional. Dado que la mayoría de ellas, desde finales del siglo XVII, se transformaron en cofradías de blancos o desaparecieron, nosotros las clasificaremos tan sólo teniendo en cuenta su situación en el momento de su fundación.

\section{Cuadro I. Cofradías de Morenos ${ }^{7}$}

6 García de la Concha, F. 1997. "Cofradías étnicas sevillanas. La hermandad de los Negritos", Actas del III Congreso Nacional de Cofradías de Semana Santa, T. I: 260. Córdoba: Cajasur.

${ }^{7}$ Fuentes: Entre los trabajos generales pueden verse: Rumeu de Armas, A. 1944. Historia de la Previsión Social en España: 272-274. Madrid: Editorial Revista de Derecho Privado. Gutiérrez Azopardo, I. s.a.: s/p. Para las cofradías andaluzas contamos con abundante bibliografía: Moreno, I. 1997. La antigua hermandad de los Negros de Sevilla: etnicidad, poder y sociedad en 600 años de historia. Sevilla: Universidad. Rodríguez Mateos, J. 1995. "De los esclavos y marginados: Dios de blancos y piedad de negros. La cofradía de los morenos de Sevilla", Actas del II Congreso de Historia de Andalucía, v. I. Córdoba: Cajasur. García de la Concha, F. 1999. "Triana: cofradías y Semana Santa, siglos XVI y XVII”, en Religión y Cultura, T. I: 447-457. Sevilla, Universidad. De obligada consulta es también la página Web de Alfonso Pozo Ruiz donde se incluye una interesante síntesis sobre las cofradías de negros de Sevilla en el siglo XVI. http://personal.us.es/alporu/histsevilla (Consulta del 2 de marzo de 2010). Sobre otras cofradías de negros en Andalucía pueden verse: Sancho de Sopranis, H. 1958. Las cofradías de morenos en Cádiz. Madrid: Instituto de Estudios Africanos. López Muñoz, L. 1995. "Las cofradías de penitencia de Granada en la Edad Moderna", Gazeta de Antropología 11: 1-10. Ortega Sagrista, R. 1957. "La cofradía de los negros en el Jaén del siglo XVII", Boletín del Instituto de Estudios Jiennenses, IV-1-2: 125-134. Aranda Doncel, J. "La devoción a la Inmaculada Concepción durante los siglos XVI al XVIII: el papel 


\begin{tabular}{|l|l|l|l|}
\hline FUNDACIÓN & INTITULACIÓN & $\begin{array}{l}\text { SEDE } \\
\text { CANÓNICA }\end{array}$ & LOCALIDAD \\
\hline 1455 & $\begin{array}{l}\text { Cofradía de negros } \\
\text { libres }\end{array}$ & -- & Barcelona \\
\hline 1472 & $\begin{array}{l}\text { Cofradía de Santiago } \\
\text { Apóstol de negros } \\
\text { libertos }\end{array}$ & $\begin{array}{l}\text { Monasterio de } \\
\text { Agustinos }\end{array}$ & Valencia \\
\hline $\begin{array}{l}1^{\text {a }} \text { mitad del } \\
\text { siglo XVI }\end{array}$ & $\begin{array}{l}\text { Nuestra Señora del } \\
\text { Rosario de Santa María } \\
\text { del Castillo }\end{array}$ & $\begin{array}{l}\text { Ermita de Santo } \\
\text { Domingo, sita } \\
\text { dentro de la } \\
\text { alcazaba }\end{array}$ & Badajoz \\
\hline 1572 & $\begin{array}{l}\text { Cofradía de mulatos de } \\
\text { Nuestra Señora de la }\end{array}$ & $\begin{array}{l}\text { Hospital de } \\
\text { Belén, collación }\end{array}$ & Sevilla \\
\hline
\end{tabular}

de los conventos cordobeses de la provincia franciscana de Granada", en http://www.rcumariacristina.como/ficheros/ (Consulta del 13-IV-2010) y Martín Casares, A. 2000. La esclavitud en la Granada del siglo XVI: 422-424. Granada: Universidad. Mira Caballos, E. 2004. "Hermandades y cofradías en la provincia de Córdoba a través del censo de 1773" Ariadna 17: 245-271. Díaz Rodríguez, V. 2009. Negros y frailes en el Cádiz del siglo XVII. Salamanca: Editorial San Esteban. Morgado García, A. 2013. Una metrópoli esclavista. El Cádiz de la modernidad. Granada: Universidad. También sobre Extremadura la bibliografía comienza a ser abundante: Tejada Vizuete, F. 2006. "La más antigua cofradía de Nuestra Señora del Rosario en la ciudad de Jerez de los Caballeros", Boletín de la Real Academia de Extremadura de las Letras y las Artes. XIV: 139-150. Mira Caballos, E. 2002. Las cofradías en Badajoz y su partido a través del censo de 1771. Badajoz: Consejería de Cultura. Manzano Marchirant, A. 1997. Semana Santa en Badajoz. Badajoz: Excmo. Ayuntamiento. Pérez Guedejo, J. J. 1999. Cofradías y hermandades en Almendral, Historia y presente. Badajoz: autoedición. Pérez Guedejo, J.J. 2000. Esclavos de Almendral, siglos XVI y XIX. Barcarrota: autoedición. Oyola Fabián, A. 2005. "Una fundación religiosa de esclavos en el siglo XVII: la cofradía de Nuestra Señora del Rosario de Segura de León", VI Jornadas de Historia en Llerena: 103-112. Llerena: Sociedad Extremeña de Historia. Periáñez Gómez, R. 2010. Negros, mulatos y blancos: los esclavos en Extremadura durante la Edad Moderna. Badajoz: Diputación Provincial. Sobre las cofradías valencianas pueden verse las obras de Cortés Alonso, V. 1964. La esclavitud en Valencia durante el reinado de los Reyes Católicos (14791516). Valencia: Archivo Municipal de Valencia y de Seser Pérez, R. 2006. "L`ermita de Sant Joan de Dénia i la confraria dels neegres: una confraria d`esclaus i una tradició religiosa i festiva amb 500 anys d'història", Aguaits 23: 7-18. Sobre Toledo: Sánchez Beato, M. A. y Santos Martín, M. 2004. "Guía bibliográfica sobre ordenanzas y reglamentos de cofradías de la ciudad de Toledo", Archivo Secreto 2: 288-314. 


\begin{tabular}{|c|c|c|c|}
\hline & Presentación & $\begin{array}{l}\text { de San } \\
\text { Salvador }\end{array}$ & \\
\hline 1575 & $\begin{array}{l}\text { Nuestra Señora del } \\
\text { Rosario, San Benito de } \\
\text { Palermo y Santa } \\
\text { Efigenia }\end{array}$ & $\begin{array}{l}\text { Convento de } \\
\text { Nuestra Señora } \\
\text { del Rosario }\end{array}$ & $\begin{array}{l}\text { El Puerto de } \\
\text { Santa María } \\
\text { (Cádiz) }\end{array}$ \\
\hline 1580 & $\begin{array}{l}\text { Nuestra Señora del } \\
\text { Rosario }\end{array}$ & $\begin{array}{l}\text { Iglesia } \\
\text { parroquial de } \\
\text { Santa Catalina }\end{array}$ & $\begin{array}{l}\text { Jerez de los } \\
\text { Caballeros } \\
\text { (Badajoz) }\end{array}$ \\
\hline 1584 & $\begin{array}{l}\text { Nuestra Señora del } \\
\text { Rosario }\end{array}$ & $\begin{array}{l}\text { Hospital de } \\
\text { Santa María de } \\
\text { Goles de Triana }\end{array}$ & Sevilla \\
\hline h. 1590 & $\begin{array}{l}\text { Nuestra Señora del } \\
\text { Rosario, San Benito de } \\
\text { Palermo y Santa } \\
\text { Efigenia }\end{array}$ & $\begin{array}{l}\text { Sucesivamente } \\
\text { en el Hospital } \\
\text { de la } \\
\text { Misericordia, la } \\
\text { ermita del } \\
\text { Rosario y el } \\
\text { convento del } \\
\text { Rosario y Santo } \\
\text { Domingo }\end{array}$ & Cádiz \\
\hline S. XVI & $\begin{array}{l}\text { Nuestra Señora de la } \\
\text { Misericordia }\end{array}$ & $\begin{array}{l}\text { Hospital de } \\
\text { Santa Ana }\end{array}$ & Málaga \\
\hline S. XVI & $\begin{array}{l}\text { Nuestra Señora de la } \\
\text { Encarnación y Paciencia } \\
\text { de Cristo }\end{array}$ & $\begin{array}{l}\text { Parroquia de } \\
\text { San Justo y } \\
\text { Pastor }\end{array}$ & Granada \\
\hline S. XVI & $\begin{array}{l}\text { Nuestra Señora del } \\
\text { Rosario }\end{array}$ & -- & $\begin{array}{l}\text { Jerez de la } \\
\text { Frontera } \\
\text { (Cádiz) }\end{array}$ \\
\hline 1606 & Dulce Nombre de Jesús & -- & Usagre \\
\hline h. 1598 & San Juan Bautista & $\begin{array}{l}\text { Ermita del } \\
\text { Loreto }\end{array}$ & $\begin{array}{l}\text { Denia } \\
\text { (Alicante) }\end{array}$ \\
\hline h. 1655 & $\begin{array}{l}\text { Congregación de } \\
\text { Nuestra Señora de la } \\
\text { Salud, San Benito de } \\
\text { Palermo y Santa }\end{array}$ & $\begin{array}{l}\text { Iglesia de } \\
\text { Santiago }\end{array}$ & Cádiz \\
\hline
\end{tabular}

${ }^{8}$ Tras una breve estancia en el hospital pasó a la iglesia parroquia del San Ildefonso. Moreno, I. 1997: 75.

${ }^{9}$ Al parecer, esta cofradía se fundó tras la expulsión de los morenos de la cofradía de Nuestra Señora del Rosario. Morgado García, A. 2013: 272. 
UNA APROXIMACIÓN AL ESTADO DE LA CUESTIÓN

\begin{tabular}{|l|l|l|l|}
\hline S. XVII & Efigenia & \\
\hline Nuestra Señora del & $\begin{array}{l}\text { Iglesia } \\
\text { parroquial }\end{array}$ & $\begin{array}{l}\text { Segura de } \\
\text { León } \\
\text { (Badajoz) }\end{array}$ \\
\hline S. XVII & San Benito de Palermo & $\begin{array}{l}\text { Iglesia de Santa } \\
\text { Escolástica }\end{array}$ & Granada \\
\hline S. XVII & San Benito de Palermo & $\begin{array}{l}\text { Convento de } \\
\text { San Francisco }\end{array}$ & $\begin{array}{l}\text { Bujalance } \\
\text { (Córdoba) }\end{array}$ \\
\hline S. XVII & $\begin{array}{l}\text { Nuestra Señora de los } \\
\text { Reyes y San Benito de } \\
\text { Palermo }\end{array}$ & -- & Jaén \\
\hline S. XVII & San Benito de Palermo & $\begin{array}{l}\text { Convento de } \\
\text { San Francisco } \\
\text { de Asís }\end{array}$ & Úbeda (Jaén) \\
\hline S. XVII & San Benito de Palermo & -- & Baeza (Jaén) \\
\hline 1747 & San Benito de Palermo & $\begin{array}{l}\text { Convento de } \\
\text { San Francisco }\end{array}$ & Madrid \\
\hline 1784 & San Benito de Palermo & $\begin{array}{l}\text { Convento de } \\
\text { San Juan de los } \\
\text { Reyes }\end{array}$ & Toledo \\
\hline S. XVIII & San Juan Bautista & $\begin{array}{l}\text { Parroquia de la } \\
\text { Magdalena }\end{array}$ & $\begin{array}{l}\text { Almendral } \\
\text { (Badajoz) }\end{array}$ \\
\hline
\end{tabular}

Son varios los aspectos que merecen ser destacados de este cuadro: en primer lugar, observamos la existencia de ciudades con más de una cofradía de morenos, sobre todo Sevilla que llegó a contar con tres, seguida de Cádiz y Granada con dos. Un aspecto que tampoco debe extrañarnos, pues, proliferaban allí donde había una alta concentración de población de color.

En segundo lugar, se verifica su presencia no sólo en localidades de mediano tamaño como El Puerto de Santa María, Úbeda o Baeza, sino también en villas muy pequeñas. Entre estas últimas, destacan un buen número de ellas en Extremadura, como las de Almendral, Jerez de los Caballeros, Barcarrota y Segura de León. Queda suficientemente demostrado que estas corporaciones también estuvieron presentes en villas pequeñas con un escaso volumen de población esclava. Desconocemos aún si esta tendencia se puede extrapolar a otras zonas de la Península Ibérica, tales como Murcia, Valencia o las dos Castillas.

En tercer lugar, confirmamos la presencia de una gran diversidad de advocaciones, aunque con un predominio de las rosarianas a las que, en

${ }^{10}$ Esta corporación fue fundada a finales del siglo XVI pero refundada como cofradía étnica en 1677, experimentando una nueva refundación en 1710, esta vez por blancos libres. Oyola Fabián, A. 2005: 106. 
ocasiones, se unían otras dos intitulaciones típicas de la raza negra: San Benito de Palermo, y la etíope Santa Efigenia. En cuanto a las primeras, conviene recordar que, tras finalizar el Concilio de Trento, se designó al portugués fray Nicolau Días O.P. para que incentivase la devoción al santísimo rosario dentro del cristianismo. Éste pretendió que estos institutos fuesen universalistas y que no discriminasen por sexo ni por estatus social, permitiendo incluso la presencia en las mismas de esclavos negros. ${ }^{11}$ El objetivo era siempre lograr la integración de estas minorías que a base de rezar el rosario y de imitar el comportamiento de los cristianos, supuestamente terminarían por aceptar los nuevos dogmas. No obstante, los problemas con los dominicos no tardaron en aparecer, pues ellos entendían que estos institutos debían residir necesariamente en sus conventos. Así, por ejemplo, la cofradía de negros de Triana, que aprobó sus reglas en 1584 bajo la advocación del Rosario, perdió un pleito con los dominicos y sus hermanos se vieron obligados a intitular su corporación como de Nuestra Señora de las Cuevas con permiso, por supuesto, de los Cartujos. ${ }^{12}$ Las dedicadas a San Benito de Palermo eran también muchas mientras que otras, como la de Jaén, la de Granada o la de Sevilla, incorporaron al santo siciliano a su intitulación a lo largo del siglo XVII. ${ }^{13}$ Una advocación que se explica perfectamente teniendo en cuenta que éste fue un santo franciscano, hijo de negros sicilianos, beatificado ya en 1643. Se trataba, pues, del santo negro por excelencia y, por tanto, era la advocación idónea para captar la devoción de las personas de color. De alguna forma, la existencia de un negro en el santoral significaba la posibilidad de redención de una raza injustamente vilipendiada. ${ }^{14}$ Las demás advocaciones son muy diversas, desde San Juan Bautista -por ser el santo más representativo del sacramento del bautismo- a la Encarnación o la Paciencia de Cristo.

$Y$ en cuarto lugar, las sedes fueron muy diversas, a saber: iglesias parroquiales, conventos, ermitas y hospitales. Obviamente, las que se ubicaban en las dos primeras estaban mucho más controladas por las autoridades eclesiásticas, mientras que las que lo hacian en ermitas u hospitales contaban con un mayor grado de libertad. En no pocas ocasiones se fundaron en ermitas que intitularon del Rosario y dieron lugar, con posterioridad, a la fundación de un convento dominico de esta advocación y su traslado al mismo. De esta forma la asociación étnica quedaba supervisada y controlada por la Orden de Predicadores. ${ }^{15}$

${ }^{11}$ Lahon, D. 2000: 275- 311.

${ }^{12}$ Pozo Ruiz, A., http://personal.us.es/alporu/histsevilla, s/p.

${ }^{13}$ Periáñez, R. 2010: 350.

${ }^{14}$ Moreno, I. 1997: 120.

${ }^{15}$ Esto dio lugar a pleitos como el mantenido entre la cofradía de los morenos de Cádiz y los religiosos del convento de Nuestra Señora del Rosario que acabó con un acuerdo firmado el 9 de diciembre de 1635. Entre otras cosas se estableció que los cargos de gobierno de la corporación los 
Cuadro II. Otras Cofradías étnicas y multiétnicas ${ }^{16}$

\begin{tabular}{|c|c|c|c|c|}
\hline $\begin{array}{l}\text { FUNDACI } \\
\text { ÓN }\end{array}$ & INTITULACIÓN & $\begin{array}{l}\text { SEDE } \\
\text { CANÓNIC } \\
\text { A }\end{array}$ & $\begin{array}{l}\text { LOCALID } \\
\text { AD }\end{array}$ & ETNIA \\
\hline S. XV & $\begin{array}{l}\text { Cristo de la Fundación } \\
\text { y Nuestra Señora de } \\
\text { los Ángeles, Los } \\
\text { Negritos }\end{array}$ & $\begin{array}{l}\text { Capilla de } \\
\text { los } \\
\text { Ángeles }\end{array}$ & Sevilla & Multiétnica \\
\hline S. XVI & $\begin{array}{l}\text { Nuestra Señora de la } \\
\text { Piedad }\end{array}$ & $\begin{array}{l}\text { Hospital } \\
\text { de San } \\
\text { Antonio } \\
\text { Abad }\end{array}$ & Sevilla & Multiétnica \\
\hline S. XVI & $\begin{array}{l}\text { Cofradía del Espíritu } \\
\text { Santo }\end{array}$ & & Sevilla & Moriscos \\
\hline S. XVI & $\begin{array}{l}\text { Nuestra Señora de la } \\
\text { Misericordia }\end{array}$ & $\begin{array}{l}\text { Hospital } \\
\text { de Santa } \\
\text { Ana }\end{array}$ & Málaga & Multiétnica \\
\hline $\begin{array}{l}\text { Fines S. } \\
\mathrm{XVI}\end{array}$ & Cofradía de San José & -- & $\begin{array}{l}\text { Villanueva } \\
\text { de la } \\
\text { Serena } \\
\text { (Badajoz) }\end{array}$ & Moriscos \\
\hline S. XVII & $\begin{array}{l}\text { Cofradía de San } \\
\text { Román }\end{array}$ & -- & Sevilla & Gitanos \\
\hline
\end{tabular}

La hermandad de los Negritos de Sevilla fue fruto de la fusión de dos hermandades hospitalarias, a saber: una de negros ubicada en el hospicio de Nuestra Señora de los Reyes, cercano al humilladero de la Cruz del Campo, que había fundado el arzobispo Gonzalo de Mena a finales del siglo XIV, ${ }^{17}$ y otra multiétnica, intitulada de Nuestra Señora de la Piedad, que residía en el hospital de San Antonio Abad. ${ }^{18}$ Pues, bien, en 1558,

nombrasen los hermanos sin intervención alguna del convento. Díaz Rodríguez, V. 2009: 49.

${ }^{16}$ Fuentes: Moreno, I. 1997. Rodríguez Mateos, J. 1995. García de la Concha, F. 1997: 259- 270. Gómez García, M. C. y Martín Vergara, J. M. 1993. La esclavitud en Málaga entre los siglos XVII y XVIII: 44-47. Málaga: Excma. Diputación Provincial. Miranda Díaz, B. y Córdoba Soriano F. de. 2010. Historia de los moriscos de Magacela: 133. Badajoz: Excma. Diputación Provincial. Jiménez Barreras, S. 2003. "La hermandad de los gitanos de San Román. Apuntes históricos", Boletín de las cofradías de Sevilla, 538: 847-848.

${ }^{17}$ Ros, C. (Dir.). 1992. Historia de la Iglesia de Sevilla: 261-262. Sevilla: Editorial Castillejo.

18 García de la Concha Delgado, F. 2002. "Antigua, Pontificia y Franciscana hermandad y cofradía de Nazarenos del Santísimo Cristo de la 
después de consumada su fusión, redactaron sus nuevas reglas, estableciéndose en el capítulo I que se admitirían como hermanos a mulatos, a indios y a negros, tanto esclavos como libres -contando, por supuesto, con la autorización de sus dueños- ${ }^{19}$ Que se incluyan los indios no tiene mucho de particular, pues, según algunos documentos de la época, a mediados del siglo XVI, vivían en Sevilla muchos indios e indias libres que los españoles los tienen por esclavos y se sirven de ellos como tales... ${ }^{20}$ No era la única multiétnica que había en la capital hispalense, pues en la cofradía del Espíritu Santo, aunque era de moriscos desde 1560 , figuraba entre sus hermanos al menos un negro subsahariano, llamado Francisco de Herrera. ${ }^{21}$ Ello nos puede estar hablando de nuevo de otra corporación multiétnica. No menos claro era el caso de la cofradía de Nuestra Señora de la Misericordia de Málaga también abierta a otras minorías étnicas. En este caso, además de negros y mulatos, podían formar parte de la misma, esclavos y libertos berberiscos. ${ }^{22}$

$Y$ finalmente tenemos alguna referencia a la fundación a finales del siglo XVI en Villanueva de la Serena (Badajoz) de una cofradía de moriscos, intitulada de San José. Al parecer, fue instituida por un morisco de origen granadino, Miguel Hernández Murcia, aglutinando en torno a ella a los conversos de la localidad que, al parecer, eran buenos cristianos. ${ }^{23}$

También conocemos algunos casos de cofradías de blancos que admitían en sus filas a negros. Fueron más excepcionales, sencillamente por el casticismo de la época que hacía que muchos cristianos viejos vieran con malos ojos estas asociaciones mixtas. Algunas de ellas es posible que en sus orígenes fueran de negros y que, con el paso de los años, se abrieran a los blancos por meros motivos de supervivencia, cuando el número de esclavos comenzó a declinar.

Fundación y Nuestra Señora de los Ángeles", en Crucificados de Sevilla, T. II: 198-200. Sevilla: ABC.

${ }^{19}$ Sánchez Herrero, J. 2002: 221.

${ }^{20}$ Mira Caballos, E. 2000. Indios y mestizos en la España del siglo XVI:

58-59. Madrid: Iberoamericana.

${ }^{21}$ García de la Concha, F. 1997: 260.

${ }^{22}$ Gómez García, M. C. 1993: 44-47.

${ }^{23}$ Miranda Díaz, B. 2010: 133. 
Cuadro III. Corporaciones de blancos que admitían o asistían a miembros de minorías étnicas ${ }^{24}$

\begin{tabular}{|c|c|c|c|}
\hline FUNDACIÓN & INTITULACIÓN & $\begin{array}{l}\text { SEDE } \\
\text { CANÓNICA }\end{array}$ & LOCALIDAD \\
\hline 1575 & Santa Veracruz & $\begin{array}{l}\text { Ermita de } \\
\text { San } \\
\text { Sebastián }\end{array}$ & $\begin{array}{l}\text { Villarrubia de } \\
\text { los Ojos } \\
\text { (Ciudad Real) }\end{array}$ \\
\hline S. XVI & Santa Veracruz & $\begin{array}{l}\text { Convento de } \\
\text { San } \\
\text { Francisco }\end{array}$ & $\begin{array}{l}\text { Berlanga } \\
\text { (Badajoz) }\end{array}$ \\
\hline S. XVI & Cofradía del Rosario & & Cáceres \\
\hline 1732 & $\begin{array}{l}\text { Hermandad del Santo } \\
\text { Rosario de Nuestra } \\
\text { Señora de la Aurora }\end{array}$ & $\begin{array}{l}\text { Parroquia de } \\
\text { Santiago }\end{array}$ & $\begin{array}{l}\text { Barcarrota } \\
\text { (Badajoz) }\end{array}$ \\
\hline
\end{tabular}

Hay que advertir que el cuadro refleja solo algunos ejemplos pero que es seguro que habría muchas más que admitirían a miembros de estas minorías. Tenemos datos concretos de la Veracruz de Villarrubia de los Ojos, fundada en 1575 en la ermita de San Sebastián y que, aunque era de blancos, admitía de facto a miembros de minorías étnicas pues encontramos a varios moriscos entre sus miembros. ${ }^{25}$ Asimismo, nos consta la presencia de moriscos en varias cofradías de Huesca -la de Santa Ana y la de San Eloy- así como en la de Nuestra Señora de la Soledad de La Algaba (Sevilla). ${ }^{26}$

La de Berlanga no admitía a negros, sin embargo sí que obligaba a sus hermanos a asistir al enterramiento de aquellos aherrojados que eran propiedad de sus cofrades. En el capítulo XIX de sus reglas se leía lo siguiente:

Ítem, ordenamos y tenemos por bien que cuando algún hermano de esta nuestra cofradía y hermandad falleciere, o su mujer o hijo de diez años arriba, o el padre o la madre, o su negro o negra del tal hermano que viviere en su casa con él y muriere en ella, no

${ }^{24}$ Fuentes: Márquez Hidalgo, F. y Valencia Rodríguez, J. M. 1993. Berlanga una villa extremeña del siglo XVI a través de dos documentos de la época: 230. Badajoz, Excmo. Ayuntamiento de Berlanga. Álvaro Rubio, J. 2005. La esclavitud en Barcarrota y Salvaleón en el período moderno (siglos XVI-XVIII). Badajoz, Excma. Diputación Provincial. Periáñez, R. 2010: 350-361.

25 Dadson, T. J. 2007. Los moriscos de Villarrubia de los Ojos (S. XVXVIII): historia de una minoría asimilada, expulsada y reintegrada: 670 . Madrid: Iberoamericana.

${ }^{26}$ Actualmente intitulada del Santo Entierro de Nuestra Señora de la Soledad. Al parecer fue inicialmente fundada por moriscos. Cit. en la Web de la hermandad, http://www.telefonica.net/web2/soleanos (consulta del 25-III-2010). 
habiendo en ello fraude ni cautela, o marido o mujer, sean todos los hermanos a ir a su enterramiento... ${ }^{27}$

Con frecuencia, el hecho de que el cabeza de familia estuviese en una corporación implicaba la extensión de la mutua a sus familiares en primer grado, es decir, a su esposa e hijos y, como en el caso de Berlanga, también a su servidumbre.

De la cofradía del Rosario de Cáceres sabíamos que era de blancos, sin embargo, en 1546, Elvira Paredes, en su testamento, otorgó la libertad a su esclavo Francisco, dándole 1.000 maravedís y ordenando a sus albaceas que le pagasen su entrada en dicho instituto. ${ }^{28}$ Todo parece indicar que estamos nuevamente ante una de esas cofradías abiertas que admitían a negros libertos. Diferente es el caso de la Veracruz de Llerena que acordó, en 1570, incluir excepcionalmente a un esclavo para que portase y tocase la bocina en los desfiles procesionales. ${ }^{29}$

\section{LAS ÉLITES Y LAS COFRADÍAS ÉTNICAS}

Como ya hemos afirmado, si hubo cofradías de negros fue por dos motivos: uno, porque el rechazo social imposibilitaba que estas minorías se pudiesen integrar en los institutos de blancos. Por tanto, estas cofradías étnicas más que un ejemplo de integración, como se ha dicho tradicionalmente, muestran justo lo contrario, es decir, su marginación social. Y otro, porque se permitió su existencia pues, en general, los negros, a diferencia de lo que ocurrió con judíos, moriscos y gitanos, nunca fueron vistos como una amenaza, por su escasa o nula resistencia a su cristianización. ${ }^{30}$

Conocemos algunos casos concretos en que los dueños se opusieron a conceder la licencia para participar en estos institutos. Concretamente en Sevilla, algunos interpretaron ese pequeño margen de libertad como potencialmente peligroso para sus intereses clasistas. ${ }^{31}$ También en Usagre (Badajoz) detectamos reticencias de algunos propietarios a conceder licencias para la participación de sus negros en actividades cofradieras. ${ }^{32}$ Incluso, en el siglo XVIII, ciertos políticos

${ }^{27}$ Márquez Hidalgo, F. 1993: 230.

${ }^{28}$ Periáñez, R. 2010: 351.

${ }^{29}$ Ibídem: 352.

${ }^{30}$ Moreno, I. 1997: 40.

${ }^{31}$ Ibídem: 61.

${ }^{32}$ Así lo declaró Juan Gordón, vecino de Usagre, quien además añadió que había otros señores de esclavos que no habían otorgado la tal licencia. Y ello porque probablemente interpretaban que era una pérdida de tiempo que lesionaba sus intereses, además de provocar hurtos a sus amos para pagar las cuotas y pechas de la hermandad. Periáñez, R. 2010: 354. 
ilustrados como Campomanes, las vieron como una amenaza y justo por ello se decretó, el 21 de febrero de 1764, la extinción de la cofradía de negros de Cádiz. ${ }^{33}$

Sin embargo, en general, salvo estas excepciones ya citadas, tanto las autoridades como los propietarios no sólo las toleraron sino que, incluso, las auspiciaron. Los franciscanos estuvieron detrás de las fundaciones de cofradías de negros en la provincia de Jaén, erigidas o refundadas por el negro Cristóbal de Porras, siempre bajo el patrocinio de San Benito de Palermo. ${ }^{34}$ Cabría preguntarse: ¿por qué tanto las autoridades como los propietarios aceptaron de buen grado esta libertad asociativa? Por dos motivos: primero, porque los negros en principio no hacían otra cosa que mimetizar el comportamiento de los blancos por lo que, lejos de suponer una amenaza, constituían una forma más de cristianización de estas minorías. De hecho, la cofradía de los Negritos de Sevilla, en sus reglas de 1558, vedó la entrada a la misma a cualquier persona de malas costumbres como borracho, ladrón, amancebado (y) blasfemo (Cap. IV). ${ }^{35}$ Curioso, sobre todo porque se trata de calificativos que tradicionalmente se atribuían a las minorías étnicas. Lo cierto es que muchos señores de esclavos interpretaban que estas organizaciones servían de válvula de escape a las tensiones generadas por el duro servilismo al que los sometían. ${ }^{36} \mathrm{Y}$ para colmo esas tensiones no se dirigían contra sus dueños sino que morían en rencillas entre los hermanos de una misma cofradía o en áridas disputas con otras.

Y segundo, por ciertos intereses bastante menos espirituales y mucho más sórdidos; dado que los dueños estaban obligados moralmente a proporcionar un enterramiento cristiano a sus esclavos, la existencia de una cofradía de negros les podía eximir de esos gastos. Además, de alguna forma también justificaba la existencia de la esclavitud y probablemente disminuía los posibles problemas de conciencia. De hecho, se suponía que el argumento básico sobre el que se sustentaba la institución era la conversión del cautivo. De ahí que estuviese terminantemente prohibido que los moriscos y los cristianos nuevos

33 Una posición un tanto absurda, pues, pese a los temores de Campomanes, estas corporaciones no constituían ningún peligro. Más bien, se trataba de una animadversión por el boato del fenómeno cofradiero que les llevó a actuar contra ellas, empezando por las gremiales y las étnicas.

${ }^{34}$ Ortega Sagrista, R. 1957: 131.

${ }^{35}$ Sánchez Herrero, J. 2002: 222.

${ }^{36}$ El cronista Ortiz de Zúñiga lo vio así de claro cuando escribió que los dueños los dejaban ir a sus bailes y fiestas con lo cual acudían más gustosos al trabajo y toleraban mejor el cautiverio. Ortiz de Zúñiga, D. 1988. Anales eclesiásticos y seculares de la Muy Noble y Muy Leal Ciudad de Sevilla, T. III: 78. Sevilla: Ediciones Guadalquivir. 
tuviesen aherrojados. ${ }^{37}$ Por todos los motivos aludidos, no tiene nada de particular que cofradías como la de los Negritos de Sevilla contasen con la protección de todos los estamentos privilegiados, incluyendo a los caballeros maestrantes. ${ }^{38}$

Pero, no eran los únicos interesados en la existencia de estas asociaciones. También las altas jerarquías religiosas las favorecieron, por un lado, porque de esta forma se evitaban roces directos con los cristianos viejos y, por el otro, porque contribuía a la evangelización de las minorías étnicas y de alguna forma al ensanchamiento de la cristiandad. ${ }^{39}$ Incluso, los propios clérigos, es decir, los estratos más bajos del estamento eclesiástico, podían estar a favor pues siempre implicaban más ingresos, en forma de sufragios para sus iglesias, capillas o eremitorios. Tanto los dominicos como los franciscanos auspiciaron este tipo de corporaciones étnicas, los primeros fomentando la aparición de rosarios públicos de negros, que veían en los rezos una buena forma de catequización ${ }^{40} \mathrm{y}$, los segundos, impulsando la advocación del franciscano de color San Benito de Palermo. ${ }^{41}$

${ }^{37}$ Así aparece recogido en distintos documentos, por ejemplo, en un sínodo de la diócesis de Guadix y Baza, de 1556 en que se especificó que todos los dueños de esclavos fuesen cristianos viejos porque le enseñen a vivir cristianamente, so pena de estar tres meses preso en la cárcel pública. Cit. en Asenjo Sedano, C. 1997. Esclavitud en el Reino de Granada, S. XVI. Las tierras de Guadix y Baza: 17. Granada: Academia Granadina del Notariado. El 17 de noviembre de 1566 se aprobó una pragmática por la que se prohibía a los moriscos poseer esclavos, siendo una de las causas fundamentales de la sublevación de 1569. Cortés López, J.L. 1989. La esclavitud negra en la España peninsular del siglo XVI: 74-75. Salamanca: Universidad. Y nuevamente, en 1567 se pregonaron unas ordenanzas sobre moriscos en Granada, reiterando la prohibición de que estos pudiesen tener esclavos. García Arenal, M. 1975. Los moriscos: 47. Madrid: Editora Nacional. No obstante, se expidieron algunas licencias para que algunos moriscos concretos pudiesen tener esclavos. También Martín Casares, A. 2000: 77.

38 González de León, F. 1994. Historia crítica y descriptiva de las cofradías de penitencia, sangre y luz, fundadas en la ciudad de Sevilla: 143. Sevilla: Ediciones Giralda.

${ }^{39}$ Hay un interesante memorial que el doctor Pedro López dirigió al Tercer Concilio de México de 1585 en que solicitaba la creación de una cofradía de negros, similar a la de Sevilla, para favorecer la doctrina y cristiandad de los negros de la tierra. Gutiérrez Azopardo, I. s/f. s/p.

${ }^{40}$ Lahon, D. 2000: 283.

${ }^{41}$ En el convento franciscano de Bujalance los religiosos tenían un pequeño altar con al efigie de San Benito de Palermo a finales del siglo XVI. Los negros no tardaron en aglutinarse en torno a dicha devoción, constituyéndose como cofradía y erigiendo nueva capilla en el siglo XVII. Aranda Doncel, J. s/f: 85. 
A los propios esclavos también les interesaba este asociacionismo, pues haciendo ostentación pública de su fe podían justificar su sincera conversión $y$, a la postre, tener más esperanzas de conseguir su redención. No era imprescindible para su ahorramiento, aunque sí recomendable. ${ }^{42}$ De hecho, ya en las Partidas de Alfonso $X$ se estableció que los esclavos de judíos, moros o herejes quedasen libres en el mismo momento en que se produjese su conversión. ${ }^{43}$ Pero además de aumentar sus posibilidades de liberación también mejoraban en cierta medida sus condiciones de vida. ${ }^{44}$ No olvidemos que sobre el esclavo pesaban dos estigmas añadidos: su condición de pobre y de infiel. Cristianizándose eliminaban al menos la segunda de las manchas y de paso les servía para autoafirmarse frente a la clase dominante. ${ }^{45}$

A la larga estas corporaciones representaron la prueba evidente del triunfo del hombre blanco sobre el negro. De hecho, estos últimos no hacían más que reproducir los comportamientos de aquellos que los discriminaban y los mantenían en una situación servil. Por tanto, aunque en ocasiones pudieran aglutinar valores sincréticos o dar cohesión al grupo, en la práctica representaron una forma más de inserción de los esclavos en la sociedad dominante.

Huelga decir que debieron estar bien vigiladas por las autoridades eclesiásticas y civiles, despertando en ocasiones los celos de las asociaciones de blancos. Algunas de ellas estaban controladas y dirigidas por la élite local, como ocurría en el caso de la de Nuestra Señora de la Aurora de Barcarrota. Ésta admitía a blancos, negros y mulatos, teniendo su sede en la parroquia de Santiago, por lo que la capacidad de movimiento de sus hermanos de color era mínima. ${ }^{46}$ Todas las cofradías, incluidas por supuesto las de negros, estaban sujetas a la supervisión de la prelatura. Sin embargo, las que tenían su residencia canónica fuera de una parroquia o de un convento gozaban de mayores cotas de independencia. En teoría, la residencia en una ermita les daba más reputación, al no depender directamente de los presbíteros de la parroquia ni del abad del monasterio. Cofradías como la de San Juan Bautista de Denia que residía en la ermita del Loreto se podían permitir festejar sus reuniones con bailes

${ }^{42}$ Manuel Jesús Izco encontró varios casos de moros libertos como Yula, Solimán, Alí o Jamete que fueron liberados y, a juzgar por sus nombres, no parece que fueran conversos. Izco Reina, J. 2002. Amos, esclavos y libertos. Estudios sobre la esclavitud en Puerto Real durante la Edad Moderna: 113. Cádiz: Universidad.

${ }^{43}$ Cit. en Cortés López, J. L. 1989: 142.

${ }^{44}$ Seser Pérez, R. 2006: 14.

${ }^{45}$ Arias de Saavedra, I y López-Guadalupe M. L. 2002. La represión de la religiosidad popular. Crítica y acción contra las cofradías en la España del siglo XVIII: 136. Granada: Universidad.

${ }^{46}$ Álvaro Rubio, J. 2005: 174. 
y músicas autóctonos, sin molestar ni ser molestados. Aquellas ermitas que se localizaban en el campo tenían el atractivo añadido del ambiente bucólico que se respiraba y que favorecía precisamente la recuperación de sus bailes y danzas tradicionales. No obstante, la fundación en un eremitorio era un arma de doble filo ya que los elevados costes de mantenimiento del edificio corrían por cuenta de la corporación. Usualmente la cofradía debía pagar, primero, todos los gastos de reparación y mantenimiento del edificio, y segundo, a un sacristán que hiciese las veces de guarda y cuidador del recinto. Como ya hemos visto, algunas de estas cofradías de negros tuvieron su sede canónica en ermitas, como la cofradía de morenos de Badajoz, fundada en la primera mitad del siglo XVI. ${ }^{47}$ No era la única que disponía de edificio propio, pues tanto la del Puerto de Santa María como la de Cádiz dispusieron de su propio templo. $^{48}$

\section{RECHAZO, BURLA Y DISCRIMINACIÓN}

Como ya hemos afirmado, las élites no sólo permitieron este tipo de cofradías sino que las incentivaron. Sin embargo, una cosa era la élite y otra el pueblo. Entre el grueso de la población, precisamente entre aquellos que no poseían esclavos sino tan sólo el orgullo de sentirse cristianos viejos, el rechazo fue muy acentuado. Nos han llegado algunos testimonios insertos en un pleito iniciado en 1604 entre la hermandad de los Negritos de Sevilla y la señera corporación de la Antigua, Siete Dolores y Compasión. El Jueves Santo de 1604, los cortejos de ambas corporaciones se encontraron, optando los Negritos por atravesar por medio del cortejo de la hermandad de la Antigua. Este hecho fue interpretado por muchos como una afrenta intolerable. Al parecer, se produjeron graves disturbios entre los asistentes, las hermanas de la Antigua y los Negritos. Al final estos últimos acabaron tirando piedras $y$ dando palos a las hermanas de la dicha cofradía de la Antigua. ${ }^{49}$ Algunas

${ }^{47}$ De esta corporación de Morenos del Castillo, formada originariamente por los esclavos pacenses, se conservan varios expedientes en el archivo diocesano de Badajoz y merecería sin duda un estudio específico. La cofradía del Rosario de los Morenos en el Castillo contra Sebastián Zambrano para que devuelva las limosnas, 1669. Archivo Diocesano de Badajoz, cofradías Leg. 3, N. 39. También hay información en el leg. 19, N. 367. No debe confundirse con otra hermandad de Nuestra Señora del Rosario, establecida en el convento de Santo Domingo, intramuros de la ciudad y que era de blancos. Por ejemplo, Juan Grajera, en su testamento fechado el 6 de marzo de 1628, manifestó ser hermano y regidor de dicha cofradía, ubicada en el citado convento de Santo Domingo. Archivo Histórico Provincial de Badajoz Leg. 1154, fols 50r-51r.

${ }_{48}$ Parrilla Ortiz, P. 2000. La esclavitud en Cádiz durante el siglo XVIII: 160. Cádiz: Excma. Diputación Provincial.

${ }^{49}$ Romero Mensaque, C. J. s/f. Pleitos y conflictos en las hermandades sevillanas. Una aproximación histórica: 90. Sevilla: Marsay Ediciones. 
declaraciones prestadas por testigos presentados en el proceso denotan grandes dosis de fanatismo hacia estos cofrades. Por ejemplo, Francisco de Acosta declaró:

Aunque Cristo se puso en la cruz por todos, en la Iglesia hay órdenes y grados como en el cielo y no deben de ir delante de cofradía de gente blanca. ${ }^{50}$

Mero racismo de unas personas que no podían entender que unos negros, por el simple hecho de serlo, pudieran precederles en los actos públicos. En más de una ocasión, estos cofrades de color sintieron la burla del pueblo como se deduce de la declaración de otro de los declarantes, un tal Miguel Ambrosio:

Que los negros eran gente tan bárbara y ridícula que da risa en lugar de devoción, por lo cual les van silbando, y las negras van llamando a los blancos perros y judíos, y los blancos les hacen burlas con la boca. ${ }^{51}$

Otro testimonio, utiliza términos muy parecidos:

Mucha gente los está aguardando para silbarles y hacerles otras mofas y escarnios, hablarles en guineo y afrentándoles, picándoles con alfileres, de lo cual se enojan y llaman a los blancos judíos, lo cual así mismo hacen las negras que los acompañan... ${ }^{52}$

Los textos citados son suficientes para hacernos una idea de la difícil situación que vivían los Negritos en sus estaciones de penitencia. Provocaciones continuas y vejaciones verbales que unos aguantaban con resignación mientras que otros estallaban, tildándolos de judíos. Una respuesta que no debía sentar nada bien a aquellos cristianos viejos. Y es que parece obvio que los sufridos negros también sabían defenderse de los ataques verbales. La mayor parte de las afrentas se dirigía a las mujeres de color ya que, mientras los varones iban con el rostro cubierto, ellas procesionaban detrás, descubiertas y conocidas. ${ }^{53}$

204.

${ }^{50}$ Moreno, I. 1997: 83-90. También cit. en García de la Concha, F. 2002:

${ }^{51}$ García de la Concha, F. 2002: 205.

${ }^{52}$ Moreno, I. 1997: 83-90. También cit. en Romero Mensaque, C. J. s/f: 90.

${ }^{53}$ Capítulo 17 de las reglas de 1558. Sánchez Herrero, J. 2002: 224. Obviamente, las mofas y los insultos se dirigían más a ellas que iban con las caras descubiertas que a los varones que iban de disciplinantes con los rostros cubiertos. 
Lo cierto es que, pese a la dignidad con la que los Negritos intentaban realizar su estación de penitencia, no cuesta imaginar las burlas de unas personas criadas y educadas en una sociedad intransigente como era la de la España Moderna. Insultos, bromas y toda clase de vejaciones morales que provocaban la risa de los agresores y la rabia contenida de los agredidos. Para la mentalidad de la época, por muy cristianos y muy cofrades que fueran no dejaban de ser negros y, por tanto cristianos de segunda. Y para recordárselo ahí estaban los cristianos viejos.

Para colmo, cuando se produjeron altercados, las autoridades casi siempre cargaron las tintas contra los cofrades de color. El caso de los Negritos de Sevilla es muy claro, tras sus disputas con la cofradía de la Antigua, instituto de gran significación social en Sevilla, el cardenal Nuño de Guevara prohibió a los primeros procesionar en público. Los Negritos se vieron obligados a recurrir a instancias superiores, es decir, a la Santa Sede. Pero las restricciones duraron mientras vivió el cardenal de manera que el 16 de marzo de 1625 consiguieron la aprobación del Papa para evitar que estas prohibiciones se volvieran a repetir en el futuro. ${ }^{54}$

Disponemos de testimonios similares sobre la cofradía de morenos del Dulce Nombre de Jesús de Usagre, confirmando lo ya conocido para la de Sevilla. En esta localidad los vecinos se quejaban de que gente tan infame, borrachos, ladrones y alborotadores desfilase en el Corpus tan cerca del Santísimo, e incluso, delante de gente honrada y principal de la villa. ${ }^{55}$ No escatimaron tampoco en apelativos, tildando a los negros de personas muy revoltosas, inquietas y sin razón. ${ }^{56}$ Aunque no disponemos de referencias a otras hermandades étnicas es plausible pensar que este tipo de rechazo estuviese generalizado.

\section{SUS MIEMBROS}

Conocemos casos de cofradías que fueron cerradas legalmente, como la del Rosario, sita en el hospital de Santa María de los Goles de Triana, que impedía el ingreso a toda persona que no fuese de color, excluyendo no sólo a los moriscos sino también a los mulatos. ${ }^{57}$ Estos últimos crearon su propia hermandad, la de Nuestra Señora de la Presentación, también de carácter cerrado. Sin embargo, esta capacidad de cerrarse, incluso a los mulatos, es difícil de encontrar en España, pues los esclavos siempre fueron una minoría que, además, desde la segunda mitad del siglo XVII, fue progresivamente en retroceso. También la cofradía

${ }^{54}$ Carrero Rodríguez, J. 1991. Anales de las cofradías sevillanas, Sevilla:

253. Sevilla, Editorial Castillejo.

${ }^{55}$ Periáñez, R. 2010: 354.

${ }^{56}$ Ídem.

${ }^{57}$ García de la Concha, F. 1997: 261. 
de San Benito de Palermo de Madrid, ponía como condición para ser miembro ser del color del santo titular, es decir, negro. ${ }^{58}$

Sin embargo, la mayoría de ellas no fueron cerradas, al menos legalmente. $Y$ no lo fueron porque, a diferencia de lo que ocurría en América, el número de esclavos y libertos era tan escaso que debían permitir el ingreso a todo aquel que lo solicitase y pagase la cuota si querían subsistir. Prueba de que nunca estuvieron cerradas a los blancos es que con el paso del tiempo, las que sobrevivieron, experimentaron un blanqueamiento progresivo.

La cerrazón era un lujo que sólo se podían permitir las cofradías de morenos de Sevilla o la del Madrid del siglo XVIII. Si en la praxis no había blancos en las corporaciones de negros era por un rechazo personal debido a motivaciones de carácter social o cultural. Por ejemplo, en el caso de la cofradía de negros de Segura de León (Badajoz), aunque formada de facto por negros de ambos sexos, tanto libres como esclavos, el único requisito de ingreso era abonar la cuota pertinente. ${ }^{59}$ Por tanto quede claro que, aunque en sus inicios no contaron con blancos entre sus hermanos, en teoría siempre fueron abiertas porque, salvo en raras excepciones, nunca se les excluyó formalmente. En aquella sociedad casticista pocos blanco estaba dispuesto a formar parte de una cofradía de morenos. En América, por supuesto, había tal cantidad de negros que la situación era muy diferente, y ninguna cofradía de negros necesitaba de hermanos blancos para subsistir.

En teoría estaban dirigidas por libertos ya que se presuponía que un esclavo no tenía la capacidad jurídica para formar parte de una asociación. Algunas, como ocurría en las de Barcelona y Valencia, incluían en su propia intitulación lo de cofradías de negros libertos, denotando claramente la condición libre de sus asociados. Y en la mayoría se especifica que los hermanos pudiesen ser libertos o, en caso de ser esclavos, que contaran con la debida licencia de sus amos. Así se especificaba en las reglas de los Negritos de Sevilla de 1554. Igualmente, en el art. $3^{\circ}$ de las reglas de 1764 de la hermandad de morenos de Cádiz se especificaba que los hermanos podían ser libres o esclavos, pero contando estos últimos con el permiso de sus propietarios. ${ }^{60}$ También hubo otras en las que en su misma intitulación se denominaron de morenos y morenas libres y esclavos, es decir, formada por personas de color de ambos sexos, tanto libres como sujetos a servidumbre. Pero una cosa era la teoría y otra la práctica. De facto, los esclavos no sólo formaban parte de estas corporaciones sino que solían ser mayoría, simplemente porque su número fue siempre muy

\footnotetext{
${ }^{58}$ Ibídem: 273.

${ }^{59}$ Oyola Fabián, A. 2005: 109.

${ }^{60}$ Morgado García, A. 2013: 275.
} 
superior al de libertos. Ya Félix González de León escribió en 1852 que la citada cofradía de los Negritos de Sevilla congregaba no sólo a libertos sino también a decenas de esclavos que contaban con la preceptiva autorización. Efectivamente, dado que había más esclavos que libertos, una buena parte de sus hermanos eran aherrojados. Pero, es más, en las cofradías de Denia, Málaga o Sevilla, nos consta que muchos de sus hermanos mayores fueron esclavos negros. Incluso en la cofradía de negros de Nuestra Señora de los Reyes de Jaén, su primer prioste y fundador fue Juan Cobo, esclavo de un tal Francisco Cobo del Rincón. ${ }^{61} Y$ no sólo admitían a negros libres u esclavos, sino también a todo tipo de mulatos y cuarterones, como era el caso de la de morenos de Badajoz.

Desde la segunda mitad del siglo XVII también fue habitual la incorporación progresiva de blancos. Obviamente, cuando la esclavitud comenzó declinar, la mayoría de las corporaciones desapareció y otras fueron incorporando masivamente a blancos que no tardaron en hacerse con el control. La cofradía rosariana de Nuestra Señora de la Aurora de Barcarrota, fundada en la tardía fecha de 1732 , no tuvo más remedio que instituirse como mixta, admitiendo a blancos, negros y mulatos. ${ }^{62}$ También la de Badajoz que perduró hasta el siglo XIX, era al menos desde el siglo XVIII mixta, estando ya en ese siglo dominada y controlada por cristianos viejos. Precisamente, fue ese carácter abierto lo que permitió a muchas de ellas subsistir hasta la Edad Contemporánea y, en algunos casos, hasta nuestros días.

\section{SUS FINES}

Estas asociaciones mimetizaron el comportamiento de las corporaciones de blancos, siendo sus objetivos muy similares, es decir, el culto a sus titulares y la asistencia a sus mutualistas. ${ }^{63}$ La atención a los enfermos, la asistencia a los funerales y la financiación de sufragios formaban una parte fundamental de su propia razón de ser. Y de paso, aunque más como consecuencia que como causa, sirvió para reforzar la identidad de unas minorías étnicas que se encontraban en una situación social muy desfavorecida.

Cuando los esclavos enfermaban o envejecían comenzaban a suponer una pesada carga para sus dueños. En el mejor de los casos se les permitía permanecer en el hogar al que habían dedicado su vida y, en

${ }^{61}$ Ortega Sagrista, R. 1957: 130.

62 Álvaro Rubio, J. 2005: 174.

${ }^{63}$ Según Isidoro Moreno las cofradías tenían un triple cometido: uno, promover los cultos en honor de sus titulares. Dos, conseguir mejoras espirituales entre sus miembros mediante los cultos. $Y$ tres, practicar la asistencia entre los mutualistas. Moreno, I. 1985. Cofradías y hermandades andaluzas: 23. Sevilla: Editoriales Andaluzas Unidas. 
caso de fallecimiento, el dueño les sufragaba una sepultura en el templo, en aquellos lugares destinados a las personas más pobres. ${ }^{64}$ En el peor de los casos, el propietario adoptaba la diabólica decisión de liberarlo por lo que el infortunado liberto acababa sus días malviviendo de la mendicidad. ${ }^{65}$ Nos llama mucho la atención que haya muchísimos más bautizos de negros que entierros. $\mathrm{Y}$, obviamente, morirse se morían, pero muchos de esos liberados no constan ya como esclavos y nos pasan desapercibidos entre las miles de partidas sacramentales de las parroquias.

Por ello, nada tiene de particular el origen hospitalario de muchas de ellas. De hecho, el inicio remoto de la cofradía de los Negritos de Sevilla fue el hospicio para negros que, a finales del siglo XIV, fundó el arzobispo Gonzalo de Mena y Roelas. Además de enterrar y ofrecer sufragios, se ocupaba especialmente de los enfermos aunque más en su vertiente espiritual que sanitaria, velando por que confesara, comulgara y, en última instancia, se le administrase la Extremaunción. ${ }^{66}$ También la cofradía de la Misericordia de Málaga, formada por esclavos y libertos, estaba ubicada en el hospital de Santa Ana, siendo su principal cometido la asistencia de sus mutualistas en la enfermedad y en la muerte. ${ }^{67} \mathrm{E}$ igualmente, la de San Benito de Palermo de Madrid, tenía como objetivo fundamental la asistencia a sus hermanos en la enfermedad y, en caso de fallecimiento, la financiación de un enterramiento cristiano digno.

Otras, como la de Nuestra Señora de la Aurora de Barcarrota, no asistían en la enfermedad sino que sus hermanos se limitaban a acudir a la puerta de la morada del enfermo a rezar por él. ${ }^{68}$ Una vez fallecido el

64 Había excepciones, especialmente cuando mediaba una gran afectividad entre el dueño y el esclavo. Conocemos casos de propietarios que trataron en la praxis a su esclava como si fuera su mujer, inhumando a sus hijos en lugares preferentes. Por ejemplo, en Solana de los Barros (Badajoz) Pedro García Bermejo, en 1660, dispuso el enterramiento de su esclava María en la primera nave de la ermita de los Mártires, porque la parroquial estuvo en obras hasta 1698. Por su parte, Inés Rodríguez pagó diez misas por su esclava María, fallecida en 1696. Libros de Bautismo de la Parroquia de Santa María Magdalena de Solana de los Barros. Centro Cultural Santa Ana, Película 484.

65 Una idea que no es nueva, pues, Miguel de Cervantes aludió en El Quijote a esta actitud de los dueños que liberaban a los negros para no tenerlos que mantener en la vejez y echándolos de casa con título de libres, los hacen esclavos del hambre, de quien no piensan ahorrarse sino con la muerte.

${ }^{66}$ Capítulo 23 de sus reglas de 1558. Sánchez Herrero, J. 2002: 226. También en Moreno, I. 1997: 66.

${ }^{67}$ Los estatutos de esta cofradía no han aparecido pero conocemos algunos de estos aspectos por otras referencias documentales. Véase a Gómez García, M. C. 1993: 44-47

${ }^{68}$ Álvaro Rubio, J. 2005: 176. 
mutualista, costeaba el entierro y ofrecía seis sufragios por su alma, además de las doce misas anuales de réquiem por todos los hermanos difuntos. Igualmente los morenos de Badajoz tampoco asistían a sus miembros en la enfermedad, limitándose a pagar el entierro y los sufragios establecidos.

Pero, ¿Qué ocurría si en alguna localidad no había cofradía hospitalaria de negros? Si era esclavo dependía de la buena voluntad de su dueño, si era liberto de la beneficencia social. Normalmente todo quedaba en manos de la caridad cristiana. En localidades como Carmona (Sevilla), que teniendo una nutrida población esclava, no poseía ninguna hermandad de morenos, el hospital de la Misericordia y Caridad, altruistamente acogía en sus instalaciones a todo tipo de pobres, independientemente de su color, enterrándolos luego en su capilla, con la única condición de que fuesen cristianos. ${ }^{69}$

Como todas las cofradías también tenían su lado devocional, realizando casi todas ellas rosarios públicos. La de Barcarrota obligaba a sus miembros a cantar el rosario todas las noches, unos días por las calles $y$, otras, en el interior del templo parroquial donde tenían su residencia canónica. ${ }^{70}$

Tenemos constancia de la participación de negros y de miembros de otras minorías, como moriscos y gitanos, en los desfiles del Corpus Christi de muchas ciudades tanto de España como de América. ${ }^{71}$ Conviene explicar que en estos cortejos encontramos múltiples elementos paganos, como tarascas, cabezudos, gigantes y grupos de

${ }^{69}$ Conocemos el caso de la negra liberta Ana, casada con un esclavo llamado Francisco, que dictó su testamento en Carmona el 18 de agosto de 1535. En él declaraba estar enferma en el hospital de la Misericordia, en cuya capilla deseaba ser enterrada. Dispuso una misa cantada de réquiem por su alma y diez misas rezadas, pagando asimismo las limosnas acostumbradas a las obras pías y un ducado a su confesor, Antón Navarro, clérigo del citado hospicio. Una vez pagado su entierro dejaba como heredero universal a dicha institución hospitalaria. Claro que en el inventario de sus bienes, apenas registró un asador, una mesa, una silla, un colchón, una almohada y dos baúles, uno pequeño y otro mediano, con algo de ropa. Difícil es que, tras pagar los gatos de su entierro, le quedase algo al hospital, pero probablemente el gesto fue reconfortante para ella y para los religiosos de la institución asistencial. Testamento de Ana, negra, Carmona 18 de agosto de 1535. Archivo de Protocolos de Carmona, escribanía de Gómez de Hoyos 1535, s/f.

${ }^{70}$ Álvaro Rubio, J. 2005: 176.

${ }^{71}$ Por ejemplo, en 1619, el cabildo de Caracas acordó que en el día del Corpus Christi las cofradías de negros y mulatos hagan las danzas que acostumbran... Gutiérrez Azopardo, I. s/f: s/p. 
bailarines. ${ }^{72}$ Danzas de romeros, zarabanda o el guineo como hacían los Negritos que participaban en el Corpus sevillano, celebrando bailes y otras diversiones. Al parecer, estos al igual que los gitanos tenían la obligación de procesionar en dicha procesión, realizando danzas de sarao y danzas llamadas de gitanos, muy populares entre la población al menos hasta principios del siglo XVIII. ${ }^{73}$ En ciudades como Ávila también había danzas de judíos, o judiadas, que tenían una larga tradición y que, al parecer, eran representadas por descendientes de judíos conversos que permanecieron en la localidad. ${ }^{74}$

Tanto la cofradía de negros de Segura de León como las de Almendral y Usagre, todas en la provincia de Badajoz, acudían a la procesión del Corpus con sus respectivas andas, portando cada una su imagen titular. Pero, es más, incluso, en localidades como Lucena (Córdoba), donde no se tiene constancia documental de la existencia de cofradías de negros, estos acudían al desfile del Corpus, realizando distintos bailes, al menos en el siglo XVII. ${ }^{75}$

\section{OSTENTACIÓN Y ORGULLO}

La mayor parte de las miles de cofradías que había en España tenían unos ingresos escasos, procedentes básicamente de las cuotas de los hermanos y de las limosnas que recogían entre los feligreses. ${ }^{76} \mathrm{Si}$ eso era así en las de blancos cuánto más debía serlo en las étnicas. Como no podía ser de otra forma, estos institutos fueron por lo general extremadamente pobres y por extensión extremadamente humildes. No

72 Sobre esta cuestión de las danzas en los cortejos religiosos puede verse la clásica obra de Caro Baroja, J. 1978. Las formas complejas de la vida religiosa: 352-353. Madrid: Editorial Akal. Sobre el Corpus sevillano existen dos trabajos monográficos imprescindibles: Lleó Cañal, V. 1980. El Corpus Christi en la historia de Sevilla. Sevilla: Excmo. Ayuntamiento y Sanz, M. J. 1997. "El Corpus en Sevillano a mediados del siglo XVI. Castillos y danzas", Laboratorio de Arte 10: 123-137.

${ }^{73}$ En Sevilla estas prácticas comenzaron a ser censuradas a finales del siglo XVII cuando el arzobispo las prohibió por irreverentes. Sin embargo, las danzas de gitanos y negros estaban tan arraigadas en la fiesta sevillana que las autoridades, temerosas de los desórdenes de la muchedumbre, acordaron permitirlas. Ros, C. 1992: 489.

${ }^{74}$ Sabe Andreu, A. M. 2000. Las cofradías de Ávila en la Edad Moderna: 316. Ávila: Excma. Diputación Provincial.

${ }^{75}$ Orsoni-Ávila F. 1997. Les esclaves de Lucena (1539-1700): 96. París: Publications de la Sorbonne.

${ }^{76}$ A finales de la Edad Moderna se estiman los ingresos medios de las 300 cofradías que había en el partido de Badajoz en 527 reales anuales, las de Toledo en 684, las de Córdoba en 714 y las del arzobispado hispalense en 977. Mira Caballos, E. 2002: 59. Obviamente, había cofradías muy ricas pero siempre fueron minoritarias. 
olvidemos que estaban compuestas por esclavos o por libertos pobres, sin posibilidades de dejar patrimonio a sus respectivas corporaciones. De hecho, conocemos muy pocos testamentos formalizados por negros y menos aún que dejen un patrimonio a alguna asociación de carácter devocional o asistencial. Por ello, las fuentes de financiación de estas cofradías eran tres: una, las modestas cuotas de los hermanos, dos, la demanda pública que periódicamente realizaban en las calles al igual que hacían las demás corporaciones, y tres, las donaciones de algunas personas ajenas a la cofradía, como ocurría en la del Rosario de Badajoz. $^{77}$

No faltaron las excepciones; corporaciones que gozaron de importantes ingresos, cierto margen de libertad y una pujanza que les hizo pleitear y ganar la precedencia a otras cofradías de blancos. Sin ir más lejos, la hermandad de los Negritos de Sevilla llegó a gozar de tales privilegios que incluso despertó los recelos de la mitra hispalense. Inicialmente funcionó como hermandad de gloria, ubicada en un pequeño hospital que se encontraba cerca de la Puerta de Carmona, ${ }^{78}$ pero posteriormente se convirtió en hermandad de penitencia, ganando pleitos de precedencia a varias cofradías señeras de la ciudad.

La de los morenos de Badajoz se atrevió a pleitear por la precedencia tanto con la señera cofradía de San José como con la de San Antonio. De su litigio con la primera no conocemos su fallo, pero de la segunda sí que ganaron una ejecutoria, el 7 de octubre de 1560, por la que el provisor le concedió su preeminencia en todos los actos públicos. ${ }^{79}$ También la de Jerez de los Caballeros (Badajoz) compitió en antigüedad y pujanza con las más antiguas de la localidad. Concretamente existían dos cofradías del Rosario, ambas fundadas en el siglo XVI, una de los morenos con sede en la iglesia de San Miguel y la de los blancos con residencia canónica en la iglesia de Santa Catalina. Sin embargo, huelga decir que la más antigua era la de los morenos de San Miguel. ${ }^{80}$

La mayoría de los enfrentamientos se dieron por la precedencia en la procesión del Corpus Christi. La de Usagre (Badajoz) pleiteó con otras corporaciones, reclamando la preeminencia en ese señalado desfile. Pero, en esto no se diferenciaban en nada de las de blancos, entre las que se produjeron infinidad de pleitos por la precedencia en los cortejos públicos. Y podríamos preguntarnos: ¿y por qué el Corpus Christi? La respuesta es obvia: históricamente era una de las fiestas religiosas más destacadas del calendario litúrgico, acaso la más importante. Se trataba

\footnotetext{
${ }^{77}$ Periáñez, R. 2010: 357.

${ }^{78}$ Montoto, S. 1999. Cofradías sevillanas: 104-105. Sevilla: Universidad.

${ }^{79}$ Manzano Marchirat, A. 1997: 34.

${ }^{80}$ Tejada Vizuete, F. 2006: 139-150.
} 
de acompañar la salida procesional de nada más y nada menos que el mismísimo cuerpo de Cristo. ¡Qué mejor lugar que el desfile del Corpus para ostentar su prestancia social! Además, no debemos olvidar que la Inquisición y sus familiares estaban siempre al acecho de cualquier persona que se apartase del dogma cristiano. No había mejor salvaguarda de la peligrosa Inquisición que participar activamente en estas manifestaciones públicas de fe.

Sobre la hermandad de San Benito de Palermo de Granada, el cronista Henríquez de Jorquera afirmó que gastaban mucho dinero en servirla con fastuosidad y ostentación. ${ }^{81}$ También de la hermandad de negros de Denia se decía a principios del XVII que, pese a que vivían prácticamente de las limosnas y de la caridad, gastaban más dinero del que ingresaban. ${ }^{82}$ Llama la atención el afán de ostentación en algunas de estas cofradías. Probablemente era una forma de reducir las diferencias con el grupo dominante, haciendo cierta la frase de Francisco de Quevedo de que buen caballero era don dinero. Y es que en parte no le faltaba razón al escudero Sancho Panza cuando afirmaba que en el mundo sólo había dos linajes, el tener y el no tener. ${ }^{83}$ Aquellas cofradías que se lo podían permitir hacían ostentación porque probablemente era una forma de sentirse menos diferentes del privilegiado mundo de sus amos.

\section{SU CARÁCTER EFÍMERO}

Casi todas las cofradías étnicas tuvieron una corta duración por motivos obvios. Las de moriscos dejaron de existir como tales desde 16091610, fecha en la que se dio por desaparecido a ese grupo étnico. ${ }^{84}$ Las de morenos languidecieron a finales del siglo XVII, desapareciendo como tales en la siguiente centuria. Solo algunas consiguieron sobrevivir hasta la Edad Contemporánea, pero como cofradías de blancos. La explicación parece obvia, el gran siglo esclavista fue el XVI que coincide con el máximo apogeo fundacional. A partir de la segunda mitad del XVII la esclavitud comenzó a declinar y con ella lo hicieron también estas cofradías étnicas. Por ello, se vieron obligadas a abrirse a la mayoría blanca, la cual terminó por hacerse con su control. Y finalmente, en el siglo XVIII casi todas ellas terminaron por desparecer como tales, paralelamente a la progresiva

${ }^{81}$ Cit. en Martín Casares, 2000: 423.

${ }^{82}$ Seser Pérez, R. 2006: 11.

${ }^{83}$ Cit. en Domínguez Ortiz, A. 2001: 232.

${ }^{84}$ Hubo muchos moriscos que consiguieron eludir el exilio, pero se quedaron individualmente y como cristianos. Los moriscos como grupo identificado y cohesionado sí desapareció. Al respecto puede verse Mira Caballos E. 2011. "Unos se quedaron y otros volvieron: moriscos en la Extremadura del siglo XVII", XXXIX Coloquios Históricos de Extremadura: 459488. Trujillo: Fundación Coloquios Históricos. 
disminución de la esclavitud. Las que sobrevivieron lo hicieron ya como corporaciones de blancos. Por tanto, está claro que el motivo principal de su desaparición no fue otro que el mismo agotamiento de la esclavitud. Simplemente, llegó un momento en que no quedaban negros para mantener dichos institutos. ${ }^{85}$ De hecho, en América, donde la población negra no decreció, estas corporaciones continuaron como tales en algunos casos hasta la Independencia, cuando la esclavitud quedó en teoría abolida. ${ }^{86}$ No obstante, el descenso del número de esclavos no fue la única causa de su desaparición. También la corriente anticlerical de algunos gobernantes ilustrados como Campomanes o Aranda, suprimieron algunas de estas cofradías, como le ocurrió a la de San Benito de Palermo de Madrid, suprimida en el decreto del 27 de julio de $1767 .{ }^{87}$

La cofradía de Nuestra Señora de la Salud de Cádiz desde el segundo cuarto del siglo XVII pasó a estar controlada por blancos, protagonizando los hermanos de color diversos altercados que provocaron un largo proceso judicial. Finalmente, fue suprimida oficialmente el 19 de junio de 1767 por falta de asociados. ${ }^{88}$ La de la Paciencia de Cristo de Granada, de negros y mulatos, fue suspendida igualmente por falta de actividad, al igual que la de Málaga que se dio por desaparecida en la segunda mitad del XVIII. Asimismo, a mediados del siglo XVII se dio por extinguida la cofradía de los negros de Triana, mientras que la de mulatos de Nuestra Señora de la Presentación de Sevilla dejó de hacer estación pública de penitencia en 1731, dándose por desaparecida en los años sesenta. ${ }^{89}$

En cambio, otras corporaciones no desaparecieron sino que se blanquearon. Así, la señera hermandad rosariana de los morenos de Cádiz y la de Badajoz perdieron su carácter étnico, continuando su andadura en abierto. Esta última tenía en 1705 dos mayordomos uno blanco y otro moreno, signo evidente de su condición mixta. ${ }^{90}$ Sin embargo, progresivamente se debió ir blanqueando, pues en un informe de su mayordomo, Pedro Rubiales, fechado el 28 de febrero de 1771, no se menciona absolutamente nada de su supuesto carácter étnico. Dada la disminución drástica del fenómeno esclavista en el siglo XVIII, había perdido su condición inicial de cofradía de negros hasta su desaparición

${ }^{85}$ Seser Pérez, R. 2006: 17.

${ }^{86}$ Por ejemplo, en Buenos Aires, en 1772, cuando en la Península estaban desapareciendo, se fundó la cofradía de negros de San Baltasar. Después de la abolición de la esclavitud y con el advenimiento del laicismo decimonónico la mayoría de estas cofradías quedó reducida a los cultos a un santo. Gutiérrez Azopardo, I. s/f: s/p.

${ }^{87}$ Rumeu de Armas, A. 1944: 273-274.

${ }^{88}$ Díaz Rodríguez, V. 2009: 25 y 61.

${ }^{89}$ Moreno, I. 1997: 75.

${ }^{90}$ Periáñez, R. 2010: 355-356. 
total a finales del primer cuarto del siglo XVIII. También la hermandad de San Juan Bautista de Denia se tornó abierta a finales del siglo XVII, desapareciendo los negros de sus listas de hermanos desde la visita pastoral de $1667 .{ }^{91}$ La cofradía de Morenos de Segura de León, refundada como étnica en 1677, retomó su andadura como cofradía de blancos 37 años después, es decir, en $1710 .^{92}$ La de los Negritos de Sevilla también se abrió a los blancos a principios del siglo XVIII, siendo controlada desde entonces por estos. Pero a diferencia de las otras, hubo hermanos negros durante buena parte de la Edad Contemporánea. ${ }^{93}$

Ahora bien hubo excepciones, es decir, cofradías que se fundaron en fechas muy tardías, bien avanzado el siglo XVIII. Concretamente, la cofradía de Nuestra Señora de la Aurora de Barcarrota se fundó como mixta en 1732 y en 1751 admitió como hermana a una mulata liberta, profesa en el convento de la Asunción de la villa. ${ }^{94}$ Mucho más efímera aún fue la vida de la ya citada corporación de negros de Madrid, que tuvo una andadura de tan sólo dos décadas, pues se fundó en 1747 y desapareció en $1767 .{ }^{95} \mathrm{Y}$ el caso más llamativo es, sin duda, el de la de San Benito de Palermo de Toledo que aprobó sus constituciones por la autoridad diocesana nada menos que en $1784 .^{96}$ Imaginamos, que su pervivencia como cofradía de negros debió ser necesariamente limitada porque ya por aquella fecha apenas quedaban aherrojados en esa ciudad. Otra cosa era Hispanoamérica, donde el volumen de negros hizo posible que se mantuvieran como corporaciones cerradas hasta bien entrado el siglo $\mathrm{XIX} .^{97}$

\section{CONCLUSIÓN}

Hemos tratado de sintetizar los aportes que en materia de cofradías étnicas han aparecido en los últimos años en distintos estudios locales sobre la esclavitud. Ha quedado demostrado que estos institutos estuvieron mucho más extendidos por la España meridional de lo que se había pensando. Fueron instituciones totalmente aceptadas y gozaron del favor de las autoridades ya que contribuían a la paz social, a la integración

${ }^{91}$ Seser Pérez, R. 2006: 17.

${ }^{92}$ Oyola Fabián, A. 2005: 106.

${ }^{93}$ González de León, F. 1994: 145. Moreno, I. 1985: 47.

${ }^{94}$ A la mulata en cuestión se le llama exactamente hermana Catalina la Morenita y, dado que se trataba de una hermandad étnica, nos induce a pensar que se tratase de una mulata o negra liberta. Álvaro Rubio, J. 2005: 174.

${ }^{95}$ Rumeu de Armas, A. 1944: 273-274.

${ }^{96}$ Sánchez Beato, M. A. 2004: 305.

${ }^{97}$ Fue el caso, por ejemplo, de la hermandad de San Juan Bautista de Santo Domingo, fundada a principios del XVII y que se mantuvo en activo hasta principios del siglo XIX. Larrazábal Blanco, C. 1998: 135. 
de todos los cristianos y a la promoción social de estas minorías desfavorecidas.

En general, aparecieron en la segunda mitad del siglo $\mathrm{XV}$, tuvieron su máximo esplendor en el siglo XVI, entrando en decadencia en el XVII y desapareciendo o abriéndose a los blancos en el XVIII, cuando el número de eslavos negros comenzó a declinar vertiginosamente. Si no hubo más corporaciones o si no se prolongaron hasta la Edad Contemporánea no se debió a ningún tipo de imperativo legal o social sino simplemente a la escasa presencia de esclavos en la mitad norte peninsular y al declive de su población en el sur desde principios del siglo XVIII.

Finalmente, ha quedado claro que lo de su carácter cerrado debe ser matizado. Muchas de ellas acogieron tanto a negros como a mulatos de muy distinta condición. Otras, incluso a moriscos e indios y casi todas terminaron aceptando a blancos. Todo parece indicar que la mayoría de ellas no eran exactamente cerradas y que si no había blancos se debía más al rechazo inicial de estos que a una prohibición de aquéllos.

\section{BIBLIOGRAFÍA}

Álvaro Rubio, J. 2005. La esclavitud en Barcarrota y Salvaleón en el período moderno (siglos XVI-XVIII). Badajoz, Excma. Diputación Provincial.

Aranda Doncel, J. "La devoción a la Inmaculada Concepción durante los siglos XVI al XVIII: el papel de los conventos cordobeses de la provincia franciscana de Granada", en http://www.rcumariacristina.como/ficheros/ (Consulta del 13-IV-2010)

Arias de Saavedra, I y López-Guadalupe M. L. 2002. La represión de la religiosidad popular. Crítica y acción contra las cofradías en la España del siglo XVIII. Granada: Universidad.

Asenjo Sedano, C. 1997. Esclavitud en el Reino de Granada, S. XVI. Las tierras de Guadix y Baza. Granada: Academia Granadina del Notariado.

Carrero Rodríguez, J. 1991. Anales de las cofradías sevillanas, Sevilla: 253. Sevilla, Editorial Castillejo.

Cortés Alonso, V. 1964. La esclavitud en Valencia durante el reinado de los Reyes Católicos (1479-1516). Valencia: Archivo Municipal de Valencia 
Cortés López, J.L. 1989. La esclavitud negra en la España peninsular del siglo XVI. Salamanca: Universidad.

Dadson, T. J. 2007. Los moriscos de Villarrubia de los Ojos (S. XV$X V I I I)$ : historia de una minoría asimilada, expulsada y reintegrada. Madrid: Iberoamericana.

Díaz Rodríguez, V. 2009. Negros y frailes en el Cádiz del siglo XVII. Salamanca: Editorial San Esteban.

Domínguez Ortiz, A. 2001. España, tres milenios de Historia. Madrid: Marcial Pons.

García Arenal, M. 1975. Los moriscos. Madrid: Editora Nacional.

García de la Concha, F. 1997. "Cofradías étnicas sevillanas. La hermandad de los Negritos", Actas del III Congreso Nacional de Cofradías de Semana Santa, T. I: 259-270. Córdoba: Cajasur.

García de la Concha, F. 1999. "Triana: cofradías y Semana Santa, siglos XVI y XVII”, en Religión y Cultura, T. I: 447-457. Sevilla, Universidad.

García de la Concha Delgado, F. 2002. "Antigua, Pontificia y Franciscana hermandad y cofradía de Nazarenos del Santísimo Cristo de la Fundación y Nuestra Señora de los Ángeles", en Crucificados de Sevilla, T. II: 191-200. Sevilla: ABC.

Gómez García, M. C. y Martín Vergara, J. M. 1993. La esclavitud en Málaga entre los siglos XVII y XVIII. Málaga: Excma. Diputación Provincial.

González de León, F. 1994. Historia crítica y descriptiva de las cofradías de penitencia, sangre y luz, fundadas en la ciudad de Sevilla. Sevilla: Ediciones Giralda.

Gutiérrez Azopardo, I. "Los negros y la Iglesia en la España de los siglos XV y XVI" en http://www.africafundación.org (consulta del 4 de marzo de 2010)

Izco Reina, J. 2002. Amos, esclavos y libertos. Estudios sobre la esclavitud en Puerto Real durante la Edad Moderna. Cádiz: Universidad.

Jiménez Barreras, S. 2003. "La hermandad de los gitanos de San Román. Apuntes históricos", Boletín de las cofradías de Sevilla, 538: 847848. 
Lahon, D. 2000. "Exclusión, intégration et métissage dans les confréries noires au Portugal XVle-XIXe siècle", en Negros, mulatos, zambaigos. Derroteros africanos en los mundos ibéricos: 275-311. Sevilla: Escuela de Estudios Hispanoamericanos.

Larrazábal Blanco, C. 1998, Los negros y la esclavitud en Santo Domingo. Santo Domingo: Librería La Trinitaria.

López Muñoz, M. L.1992. Las cofradías de la parroquia de Santa María Magdalena en Granada en los siglos XVII y XVIII. Granada: Servicio de Publicaciones de la Universidad.

López Muñoz, M. L. 1995. "Las cofradías de penitencia de Granada en la Edad Moderna", Gazeta de Antropología 11: 1-10.

Lleó Cañal, V. 1980. El Corpus Christi en la historia de Sevilla. Sevilla: Excmo. Ayuntamiento.

Manzano Marchirant, A. 1997. Semana Santa en Badajoz. Badajoz: Excmo. Ayuntamiento.

Márquez Hidalgo, F. y Valencia Rodríguez, J. M. 1993. Berlanga una villa extremeña del siglo XVI a través de dos documentos de la época. Badajoz, Excmo. Ayuntamiento de Berlanga.

Martín Casares, A. 2000. La esclavitud en la Granada del siglo XVI. Granada: Universidad.

Mena García, C. 2000. "Religión, etnia y sociedad: cofradías de negros en el Panamá colonial". Anuario de Estudios Americanos, LVII, 1: 137-169.

Mira Caballos, E. 2000. Indios y mestizos en la España del siglo XVI. Madrid: Iberoamericana.

Mira Caballos, E. 2002. Las cofradías en Badajoz y su partido a través del censo de 1771. Badajoz: Consejería de Cultura.

Mira Caballos, E. 2004. "Hermandades y cofradías en la provincia de Córdoba a través del censo de 1773" Ariadna 17: 245-271.

Mira Caballos, E. 2004. Las reglas del Gran Poder de Sevilla de 1570. Transcripción y estudio. Sevilla, Excmo. Ayuntamiento. 
Mira Caballos E. 2011. "Unos se quedaron y otros volvieron: moriscos en la Extremadura del siglo XVII", XXXIX Coloquios Históricos de Extremadura: 459-488. Trujillo: Fundación Coloquios Históricos.

Miranda Díaz, B. y Córdoba Soriano F. de. 2010. Historia de los moriscos de Magacela. Badajoz: Excma. Diputación Provincial.

Montoto, S. 1999. Cofradías sevillanas. Sevilla: Universidad.

Moreno, I. 1985. Cofradías y hermandades andaluzas. Sevilla: Editoriales Andaluzas Unidas.

Moreno, I. 1997. La antigua hermandad de los Negros de Sevilla: etnicidad, poder y sociedad en 600 años de historia. Sevilla: Universidad.

Morgado García, A. 2013. Una metrópoli esclavista. El Cádiz de la modernidad. Granada: Universidad.

Orsoni-Ávila F. 1997. Les esclaves de Lucena (1539-1700). París: Publications de la Sorbonne.

Ortega Sagrista, R. 1957. "La cofradía de los negros en el Jaén del siglo XVII", Boletín del Instituto de Estudios Jiennenses, IV-1-2: 125-134.

Ortiz de Zúñiga, D. 1988. Anales eclesiásticos y seculares de la Muy Noble y Muy Leal Ciudad de Sevilla, T. III. Sevilla: Ediciones Guadalquivir.

Oyola Fabián, A. 2005. "Una fundación religiosa de esclavos en el siglo XVII: la cofradía de Nuestra Señora del Rosario de Segura de León", VI Jornadas de Historia en Llerena: 103-112. Llerena: Sociedad Extremeña de Historia.

Parrilla Ortiz, P. 2000. La esclavitud en Cádiz durante el siglo XVIII. Cádiz: Excma. Diputación Provincial.

Pérez Guedejo, J. J. 1999. Cofradías y hermandades en Almendral, Historia y presente. Badajoz: autoedición.

Pérez Guedejo, J.J. 2000. Esclavos de Almendral, siglos XVI y XIX. Barcarrota: autoedición.

Periáñez Gómez, R. 2010. Negros, mulatos y blancos: los esclavos en Extremadura durante la Edad Moderna. Badajoz: Diputación Provincial. 
Rodríguez Mateos, J. 1995. "De los esclavos y marginados: Dios de blancos y piedad de negros. La cofradía de los morenos de Sevilla", Actas del II Congreso de Historia de Andalucía, v. I: 569-582. Córdoba: Cajasur.

Romero Mensaque, C. J. s/f. Pleitos y conflictos en las hermandades sevillanas. Una aproximación histórica. Sevilla: Marsay Ediciones.

Ros, C. (Dir.). 1992. Historia de la Iglesia de Sevilla. Sevilla: Editorial Castillejo.

Rumeu de Armas, A. 1944. Historia de la Previsión Social en España. Madrid: Editorial Revista de Derecho Privado.

Sabe Andreu, A. M. 2000. Las cofradías de Ávila en la Edad Moderna. Ávila: Excma. Diputación Provincial.

Sánchez Beato, M. A. y Santos Martín, M. 2004. "Guía bibliográfica sobre ordenanzas y reglamentos de cofradías de la ciudad de Toledo", Archivo Secreto 2: 288-314.

Sánchez Herrero, J. (ed.) 2002. CXIX reglas de hermandades y cofradías andaluzas, siglos XIV, XV y XVI. Huelva: Universidad.

Sancho de Sopranis, H. 1958. Las cofradías de morenos en Cádiz. Madrid: Instituto de Estudios Africanos.

Sanz, M. J. 1997. "El Corpus en Sevillano a mediados del siglo XVI. Castillos y danzas", Laboratorio de Arte 10: 123-137.

Seser Pérez, R. 2006. "L`ermita de Sant Joan de Dénia i la confraria dels neegres: una confraria d’esclaus i una tradició religiosa $\mathrm{i}$ festiva amb 500 anys d'història", Aguaits 23: 7-18.

Tejada Vizuete, F. 2006. "La más antigua cofradía de Nuestra Señora del Rosario en la ciudad de Jerez de los Caballeros", Boletín de la Real Academia de Extremadura de las Letras y las Artes. XIV: 139150. 